\title{
Innovation Propensity in the Specialized Suppliers Industry
}

\author{
Tiziana Di Cimbrini ${ }^{1}$, Fabrizio Maturo ${ }^{2}$, Stefania Migliori $^{2} \&$ Francesco Paolone $^{3}$ \\ ${ }^{1}$ Faculty of Political Sciences, University of Teramo, Italy \\ ${ }^{2}$ Department of Management and Business Administration, "G. d'Annunzio" University of Chieti-Pescara, Italy \\ ${ }^{3}$ Department of Management and Business Administration, Parthenope University of Naples, Italy \\ Correspondence: Francesco Paolone, Parthenope University of Naples, Department of Accounting, Business and \\ Economics, Via Generale Parisi 13, Naples, 80132. E-mail: francesco.paolone@ uniparthenope.it
}

Received: June 26, 2018

doi:10.5539/ibr.v11n10p129

\author{
Accepted: August 1, $2018 \quad$ Online Published: September 25, 2018 \\ URL: https://doi.org/10.5539/ibr.v11n10p129
}

\begin{abstract}
The paper focuses on the effects of technology-push and demand-pull determinants on firm's innovation propensity comparing start-ups and established firms in the specialized suppliers' industry. Specifically, it explores technology-push and demand-pull effects in isolation and in their interaction using a sample of European firms in the period 2007-2009. Our main results show that either the technology-push and demand-pull determinants exert a positive impact on innovation propensity in both start-ups and established firms, Moreover, in start-ups, we discovered that the demand-pull determinant plays a strong moderating role in the relationship between innovation propensity and the technology-push determinant. The paper contributes in making managers more aware of the effect that some choices concerning the composition of the firm's workforce may produce on the firm's innovation propensity. There are also implications for policy makers whose overemphasis on demand pull incentives may disempower the positive effect of the technology determinant on the innovation propensity of start-ups.
\end{abstract}

Keywords: innovation, technology-push, demand-pull, start-up, moderating effect, specialized suppliers

\section{Introduction}

The juxtaposing of the technology-push and demand-pull perspectives is not a recent issue in innovation studies (Schmookler, 1966; Myers and Marquis, 1969; Von Hippel, 1976; Mowery and Rosenberg, 1979; Rosenberg, 1982; Di Stefano et al., 2012; Park et al., 2012; Lubik et al., 2013; Singla et al., 2018). In the eighties, a complementary role of demand in respect of science and technology emerged in terms of the selection of a specific technological trajectory (Dosi, 1982) or, more in general, of an interactive relationship between them. The analysis of Di Stefano et al. (2012) has unveiled how more recent studies have provided a better understanding of the role of demand as a source of innovation (Langlois and Robertson, 1992; Von Hippel, 1994; Iansiti and MacCormack, 1997; Christensen et al., 2000; Von Hippel, 2001; Nambisan, 2002; Harhoff et al., 2003; Franke and Von Hippel, 2003; Lakhani and Von Hippel, 2003). Moreover, Lee (2003) demonstrated that both demand-side determinants and technology-side determinants jointly determine firm R\&D effort.

They both tend to be considered as mutually reinforcing sources of innovation so of attributing a "chicken and egg" quality to the technology-push - demand-pull issue (Chidamber and Kon, 1994) but the questions concerning their interaction patterns as determinants of firms' innovation propensity is left open in the debate. The present research fills this gap exploring the determinants of firm's propensity to both product and process innovation in terms of technology and demand determinants, which are investigated both in isolation and in their interaction. This study focuses on a sample of 2,283 European manufacturing firms belonging to the specialized supplier industry (Pavitt, 1984) in the period 2007-2009 and distinguish between start-ups and established firms. This period, which includes the recent global crisis, is characterized by circumstances that put firms' innovation propensity under pressure. Archibugi et al. (2013) demonstrated that the 2008 financial crisis substantially reduced the willingness of European firms to invest in innovation; thus, our investigation aims to discover the determinants of this willingness in the presence of adverse conditions to firms' innovation propensity.

This study explores the Pavitt category of specialized suppliers, whose activities include mechanical engineering instrumentsn and rubber and plastic products, for two different reasons. On one hand, its innovative potential is very similar to that of science-based firms, on average a high to medium number of innovations and a high 
percentage of product innovation according to Pavitt et al. (1989). Similarly, Souitaris (2002) found that the science based and the specialized supplier firms had higher rates of innovation and that there are not significant differences between their two "high-innovation" trajectories. On the other hand, it faces demand characteristics different from the science-based category because specialized suppliers' end users are other productive units. This more rational and technical demand increases the likelihood of producer-user collaboration in innovation and, consequently, a more direct link between the demand side and the innovation effort. Thus, the ability to focus at the same time on internal (tacit knowledge and experience of the technicians) and external sources (interaction between producers and users) of innovation (Malerba and Orsenigo, 1997; Malerba, 2004) makes more intense the link between the innovation propensity of this industry and both technology and demand determinants.

Furthermore, this study separately considers start-ups and established firms because liquidity-constrained firms are particularly sensitive to sales in deciding their investment in innovation such as their R\&D expenditure (Piva and Vivarelli, 2007). Start-ups usually face more liquidity constraints than established firms so that we would expect a more intense sensitiveness to sales in this type of firms. Other reasons concern their widely acknowledged role in the economic development and the differences compared to established firms in their innovation activities (Criscuolo et al., 2012).

Results show that both technology and demand determinants exert a positive impact on innovation propensity in both start-ups and established firms but, in start-ups, the demand determinant plays a strong moderating role in the relationship between innovation propensity and the technology push determinant. Conversely, in the established firms, the interaction between the demand and technology-push determinants is not statistically significant. In addition, the emerging interaction pattern between technology and demand determinants in start-ups also questions the existence of a permanent virtuous circle between them in affecting innovation propensity. This is the main contribution of our study, which, by adopting an under-utilized method as suggested by Di Stefano et al. (2012) to enrich the field with heterogeneous perspective, provides an overview of unexpected interaction dynamics between technology and demand determinants of innovation propensity.

This study also provides other contributions for the literature on innovation in start-ups. First, differently from previous literature about the innovative activities of start-ups compared to those of established firms (Sorensen and Stuart, 2000; Katila and Shane, 2005; Balasubramanian and Lee, 2008; Criscuolo et al., 2012), this paper explores interaction patterns. Second, while most studies have focused on the innovative behaviour of high-tech/science-based firms (Parry and Song, 1993; Himmelberg and Petersen, 1994; Irwin and Klenow, 1996; Liu and Buck, 2007; Pla-Barber and Alegre, 2007; Coad and Rao, 2008), it investigates the determinants of their innovation propensity in an under-explored industry, which is at the base of the innovative dynamics of the entire business system. In fact, the specialized suppliers focus on the introduction of product innovation, which is addressed mainly to other sectors (Gehringer, 2010), and they provide specialized inputs into complex and interdependent production systems (Archibugi, 2001).

This paper is structured as follows. Section 2 introduces our theoretical framework and develops our hypotheses. Section 3 describes the data whereas Section 4 illustrates the methodology and results. Finally, Section 5 presents the discussion and some concluding remarks.

\section{Literature Review and Development of Hypotheses}

\subsection{Technology Determinant}

The technology determinants of innovation propensity represent internally originated factors concerning the firm's acquired knowledge and its potential development. "The core of the science and technology-push argument is that advances in scientific understanding determine the rate and direction of innovation" (Nemet, 2009, p. 701).

Kline and Rosenberg (1986, p. 287) argued that a basic component of science that affect innovation is the current totality of stored human knowledge because most innovation is done with the available knowledge already in the heads of the people in the organization. The extent to which firms have access to a stock of knowledge makes the firm aware of the variety of needs concerning innovation activities that could be expected to emerge. This is because the need for research implies entering a technology system where the knowledge, the skills, and the experience required are interrelated and support each other (Freeman and Soete, 1997, p. 361).

Consistently with Horbach (2008), who considered the percentage of high qualified employees with respect to all employees as an indicator of the technological capabilities, and with Doloreux et al. (2016), who associate innovation capabilities to a comprehensive set of characteristics of a firm including the stock of human capital, 
this study relates innovation propensity to the quality of the human capital of the firm (Wu et al., 2008; Monreal-Pérez et al., 2012; Higuchi et al., 2015). This quality has been often associated to the educational level of the human capital. Hofheinz (2009) has proposed that educational attainment is an effective means of assessing levels of skills in a workforce, where higher skills indicate tertiary attainment or equivalent and medium skills indicate attainment of secondary or equivalent education. Freeman and Soete (1997, p. 361) argued that much of the knowledge required to enter a technology system in its early phase is public knowledge available at universities so that the availability of well-qualified university personnel is an opportunity for entering into new products in a new technology system in its early phases. According to Lundvall and Johnson (1994), higher education impacts on innovation in two ways; firstly, graduates can invent and develop new technologies and, secondly, these higher educated graduates can exploit technological progress. On the other hand, D'Este et al. (2014) demonstrated that the proportion of the firm's total employees with a higher education degree is a critical factor in reducing the barriers to innovation while McGuirk et al. (2015) consider education one of the elements of the holistic concept of Innovative Human Capital.

Because the higher the stock of qualified human capital, the higher the firm's absorptive capacity which is critical to the organization's innovative capabilities (Cohen and Levinthal, 1990), this variable is expected to positively affect innovation propensity in both start-ups and established firms. However, the intensity of their effect is expected to be more intense in established firms. Because the absorptive capacity resides in routines and processes by which firms acquire, assimilate, transform, and exploit knowledge (Zahra and George, 2002) and, because these routines and processes are in the embryonic stage in the start-ups, established firms should be more able in leveraging existing qualified knowledge by incorporating it into investments in innovation. Based on the latter arguments, the following hypothesis has been tested:

Hypothesis 1.a: The stock of qualified human capital positively affects the innovation propensity in young specialized suppliers.

Hypothesis 1.b: The stock of qualified human capital positively affects the innovation propensity in mature specialized suppliers.

Hypothesis 1.c: The positive effect of the stock of qualified human capital on innovation propensity is more intense in the mature than in the young specialized suppliers.

\subsection{Demand Determinant}

The demand-pull determinants of innovation investments represent external originated factors concerning market demands. Demand makes firms to work on certain problems (Rosenberg, 1969) affecting the rate and direction of innovation. This rising demand may induce an increase in the innovation effort as stressed in the literature (Schmookler, 1962; Schmookler, 1966; Mowery \& Rosenberg, 1979; Brouwer \& Kleinknecht, 1996), and the demand-pull impact needs to be checked for the different technological regimes which characterise different industrial sectors (Piva \& Vivarelli, 2007). This study expects a strong positive impact of demand-pull determinants on innovation propensity of specialized suppliers because they live in symbiosis with their customers (Archibugi, 2001), who are performance sensitive, and thus specialized suppliers are mostly oriented towards product innovation (Pavitt, 1984).

The more relevant question concerning the demand-pull impact resides in the definition of the demand factor. Mowery \& Rosenberg (1979, p. 140) argued that, to be taken seriously, demand-pull hypotheses must base themselves upon a precise concept, denoting a systematic relationship between prices and quantities, one devolving from the constellation of consumer preferences and incomes. The relationship is even closer if we consider that part of the total sales concerning produced-to-order goods because they directly incorporate the expressed needs of the customer.

Several studies found an association between innovativeness and the closeness of relationships with customers (Cantista \& Tylecote, 2008). Given the close relationship between specialized suppliers and their customers, we would expect that this specific market demand represents the most sales of these firms and exerts a significant positive effect on the innovation propensity for both start-ups and established firms. It is because more likely produced-to-order goods are customized goods that most frequently require an innovation investment making this latter a "responsive" mechanism to the market needs. We would also expect that the positive effect of the sales of produced-to order goods is more intense in start-ups than in established firms for two different reasons. First, younger firms usually deal with greater financial constraints and uncertainty, and, as suggested by Hall et al. (1998), firms affected by liquidity constraints and credit rationing should be more dependent on internal cash flow, and thus they should be more sensitive to current sales when deciding to engage in innovation investment (Goodacre \& Tonks, 1995; O' Sullivan, 2005). Second, new firms are more likely to use innovation to acquire 
market share from incumbent firms or to open new markets. Thus, in the trade-off between exploitation and exploration effort (March, 1991) towards innovation, start-ups should be more sensitive to explore new markets opportunities signalled by the demand. Based on the latter arguments, this study tests the following hypotheses:

Hypothesis 2.a The sales of produced-to order goods positively affect the innovation propensity of the young specialized suppliers.

Hypothesis 2.b The sales of produced-to order goods positively affect the innovation propensity of the mature specialized suppliers.

Hypothesis 2.c The positive effect of sales of produced-to order goods on innovation propensity is more intense in the young than in the mature specialized suppliers.

2.3 The Moderating Role of the Demand in the Relationship between the Percentage of University Graduates in the Workforce and the Innovation Propensity

As well as each invention results from the link between a purpose and a principle (some generic use of an effect) that will satisfy it (Arthur, 2007), both supply and demand side determinants are necessary to explain innovation and, consequently, the innovation propensity. The literature agrees on the need to consider the positive interaction effect exerted by technology push and demand-pull determinants (Di Stefano et al., 2012) and several studies emphasized the role of the combination of demand-pull and technology-push indicators (Freeman, 1974; Kleinknecht and Verspagen, 1990; Crepon et al., 1998; Lee, 2003) so that the reduction of the innovation propensity to two separate technology push and demand-pull causal determinants is limiting. Thus, we also consider the relationship between the percentage of the turnover made up by sales of produced-to order goods and the stock of qualified human capital.

Given the results emerging from previous literature, this study expects a positive effect of the interaction on innovation propensity in both start-ups and established firms with a moderating role played by the turnover made up by sales of produced-to order goods. Specifically, this study assumes that the demand determinant potentiates the positive effect of the stock of qualified human resources expressing the technological capabilities of the firm because sales provide the financial support to undertake investments in innovation and at the same time signal market opportunities. This study also expects a more intense moderating role in start-ups because, due to their higher sensitivity to the demand determinants hypothesized in the previous section. Based on the latter arguments, the following hypotheses have been tested:

Hypothesis 3.a: The relationship between the stock of qualified human capital and the innovation propensity of the young specialized suppliers will be moderated by the sales of produced-to order goods. Increased levels of sales of produced-to order goods will increase the contribution of the qualified human capital to innovation propensity.

Hypothesis 3.b: The relationship between the stock of qualified human capital and the innovation propensity of the mature specialized suppliers will be moderated by the sales of produced-to order goods. Increased levels of sales of produced-to order goods will increase the contribution of the qualified human capital to innovation propensity.

Hypothesis 3.c: The moderating role played by the sales of produced-to order goods in the relationship between the stock of qualified human capital and innovation propensity is more intense for the young than for the mature specialized suppliers. Increased levels of sales of produced-to order goods will increase the effect of qualified human capital to innovation propensity more in start-up than in established firms.

\section{Data}

\subsection{The Dataset}

The data of this study are taken from the "EU-EFIGE/Bruegel-UniCredit dataset" (EFIGE Dataset), collected within the "EFIGE project" (European Firms in a Global Economy: internal policies for external competitiveness) and realized by the Directorate Research of the European Commission through its 7the Framework Programme. The dataset is placed at the disposal of researchers on the EFIGE-Bruegel web site. This database combines measures of firms' international activities with quantitative and qualitative information of 14,345 manufacturing firms (with more than 9 employees) belonging to seven European Countries (Germany, France, Italy, Spain, United Kingdom, Austria, and Hungary) on several areas: firms' structure, workforce, R\&D investments (and related financing), innovation, internationalization processes, market structure and financial structure. The above areas are organized around six different sections in the questionnaire for a total of 150 items.

The database has been built to match three criteria. First, the availability of an adequately large target sample of 
firms (a total of 16,000 operable questionnaires conducted on 3000 firms for large countries, and 500 firms for smaller countries). Secondly, a minimum response rate of $85-90 \%$ for 5 to 10 key questions; a minimum response rate for 10/15 important questions not below 70\%; an overall average of response rates not below $60 \%$ for the remaining part of the questionnaire. Lastly, a proper stratification of the sample by using three dimensions: industries (11 NACE_CLIO industries codes), regions (at the NUTS-1 aggregation level) and size class (10-19; 20-49; 50-250; more than 250 employees).

The survey was conducted using the questionnaire instrument reaching a total of around 135,000 companies contacted for all seven countries ${ }^{1}$. The data was collected by a survey in 2010 covering the years from 2007 to 2009 (Altomonte and Aquilante, 2012).

This study considers two different groups of companies belonging to the specialized suppliers' industry. Because we aim to compare start-ups and established firms, we select all the specialized suppliers available in the EFIGE dataset. After eliminating firms with missing data, and even those with obviously incorrect data (i.e. above $100 \%$ percentages and similar inconsistencies), we obtain a sample of 2,283 companies. To avoid putting too much interaction terms, this analysis splits the two types of enterprises and make separate models for start-ups and established firms. With this procedure, the analysis gets two groups: the first one is composed by 159 start-ups, and the second one is made-up of 2,124 established firms. The start-ups' group consists of those companies with less than 6 years of life; instead, the established firms are those companies with more than 5 years of life.

This analysis stresses that we do not make a sampling (we just take all the specialized suppliers available). Naturally, a sampling procedure was performed by those who have created the EFIGE dataset, but as explained in detail in their accompanying documents, a stratified sampling was carried out to ensure a very representative sample of the population of the European companies. The samples' sizes of the two types of companies are different because they reflect the existing proportions of the population of the considered sector.

\subsection{Variables Description}

\subsubsection{Dependent Variable}

Our dependent variable is the propensity of the firm to invest in innovation (product and process innovation). Existing studies generally refer to $R \& D$ investment as a proxy of the propensity to innovation investment because it represents a pre-requisite for creating or improving new products or technologies. However, R\&D investment is systematically underestimated in small firms (Archibugi and Pianta, 1996; Patel and Pavitt, 1995) and it may be a non-exhaustive representation of all types of expenses in innovation. The measure of the firm's propensity to invest in innovation (INN_PRO) is a dummy variable that equal to one, if a firm, during 2009, has decided "not to postpone" investments in product or process innovation, and takes the value of zero otherwise.

\subsubsection{Independent Variables}

Concerning the "technology-push" determinant, it seems difficult to find an operational variable that perfectly matches the notion of stock of qualified human capital. In this study, a proxy variable that closely represent the knowledge and skills of the firm's personnel is used, i.e. the percentage of university graduates in the workforce of the firm in 2008 (GRAD). As discussed in the hypotheses section, the previous literature has already assessed this variable to measure the effort of firms to store qualified knowledge. The "demand-pull" determinant is measured as the percentage of firms' turnover made up by sales of produced-to-order goods in 2008 (PO).

\subsubsection{Control Variables}

In recent years, the literature has highlighted the key role of firm size in explaining firms' innovation (Damanpour, 2010). Some studies have emphasized the advantage of large firms (Cohen and Klepper, 1996; Chandy and Tellis, 2000; Fritsch and Meschede, 2001) whereas others have emphasized the advantage of small firms (Audretsch and Vivarelli, 1996; Rogers, 2004; Nieto and Santamaría, 2010). To consider the effect of firms' size on innovation, the total number of employees in 2008 (EMPL) and the annual turnover of firms in 2008 (TURNOV) have been used to control. Moreover, the literature suggests that the lack of appropriate financial resources and the regulation (legislation, norms, regulations, standards, and taxations) are important obstacles to innovation (Mohnen and Röller, 2005). Specifically, firms' financial constraints may lead to problems of underinvestment in R\&D expenditure (Bond et al., 2003; Hall, 1992, 2002; Himmelberg and Petersen, 1994; Mulkay et al., 2001) and may be an obstacle to firms' innovation propensity. Financial constraints may be particularly binding for young firms (Czarnitzki and Hottenrott, 2011) and start-ups, which have not yet an established reputation to external stakeholders (banks) (Berger and Udell, 2002; Peternsen and Rajan, 1995), and thus the latter might still not able to generate performance as a guarantee towards third-party lenders (Schafer et al., 2004). 
Firms belonging to a group can have access to intra-group flows of resources for funding innovation projects (Czarnitzki and Hottenrott, 2011). Moreover, business group's capital market may represent a way to overcome external financial constraint or support firms when they suffer negative cash flows (Buchuk et al., 2014; Gopalan et al., 2007; Khanna and Yafeh, 2005). Therefore, to consider the financial constraints' effects on investment in innovation, and on the basis of Guzzini and Iacobucci (2014), who found that group affiliation has a strong impact on R\&D propensity, a dummy variable (GROUP) has been included. It is equal to one, if a firm is part of a group, and takes the value of zero, otherwise.

Moreover, this analysis considers that regulation can facilitate or inhibit investment in innovation by providing financial incentives or special tax allowances (Rennings and Rammer, 2011; Czarnitzki and Lopes-Bento, 2014; Cecere and Corrocher, 2016). Then, to control the effect of the regulation, the following dummy variables have been included: BEN_INV that is equal to one if, during 2009, the firm has benefitted from special tax allowances, and takes the value of zero, otherwise; and BEN_PUB, that is equal to one, if during 2009, the firm has benefitted from public financial incentives, and it is equal to zero, otherwise. All the variables used in the models are detailed in Appendix 1. Finally, we underline that our models do not consider age and sector because a distinction has been made in the starting selecting procedure, by considering only specialized suppliers and distinguishing two groups according to their age.

\subsubsection{Descriptive Statistics}

Table 1 shows the descriptive statistics of the variables. Specifically, 56\% of start-ups and $53 \%$ of established firms are characterized by INN_PRO activities during 2009. About EMPL we remark that the EFIGE-Dataset contains data of manufacturing firms with more than 9 employees. In addition, also for ensuring the anonymity of the companies, if they have more than 500 employees, the dataset does not detect it, and note that they have only 500. For this reason, the few companies with more than 500 employees have not been considered, because the analysis would not have been accurate.

Table 1. Descriptive statistics for start-ups and established firms

\begin{tabular}{|c|c|c|c|c|c|c|c|}
\hline \multicolumn{8}{|c|}{ START-UPS } \\
\hline & FIRMS & MIN & MAX & RANGE & MEDIAN & MEAN & SD \\
\hline INN_PRO & 159 & 0 & 1 & 1 & 1 & 0.56 & 0.50 \\
\hline TURNOV & 159 & 1 & 3 & 2 & 2 & 1.64 & 0.55 \\
\hline EMPL & 159 & 10 & 473 & 463 & 30 & 58.9 & 77.17 \\
\hline BEN_INV & 159 & 0 & 1 & 1 & 0 & 0.21 & 0.41 \\
\hline BEN_PUB & 159 & 0 & 1 & 1 & 0 & 0.18 & 0.39 \\
\hline GROUP & 159 & 0 & 1 & 1 & 0 & 0.21 & 0.41 \\
\hline $\mathrm{PO}$ & 159 & 0 & 100 & 100 & 100 & 65.97 & 42.24 \\
\hline GRAD & 159 & 0 & 70 & 70 & 5.71 & 9.21 & 11.93 \\
\hline \multicolumn{8}{|c|}{ ESTABLISHED FIRMS } \\
\hline & FIRMS & MIN & MAX & RANGE & MEDIAN & MEAN & SD \\
\hline INN_PRO & 2124 & 0 & 1 & 1 & 1 & 0.53 & 0.50 \\
\hline TURNOV & 2124 & 1 & 3 & 2 & 2 & 1.71 & 0.55 \\
\hline EMPL & 2124 & 10 & 492 & 482 & 28 & 56.69 & 76.34 \\
\hline BEN_INV & 2124 & 0 & 1 & 1 & 0 & 0.23 & 0.42 \\
\hline BEN_PUB & 2124 & 0 & 1 & 1 & 0 & 0.19 & 0.39 \\
\hline GROUP & 2124 & 0 & 1 & 1 & 0 & 0.20 & 0.4 \\
\hline $\mathrm{PO}$ & 2124 & 0 & 100 & 100 & 100 & 69.39 & 40.13 \\
\hline GRAD & 2124 & 0 & 100 & 100 & 5.88 & 9.63 & 13.48 \\
\hline
\end{tabular}

With reference to TURNOV, the dataset adopts the following firm's classification: less than 1 million euro, 1-2 million euro, 2-10 million euro, 10-15 million euro, 15-50 million euro, 50-250 million euro, and more than 250 million euro. Because the original variable is divided into seven different size classes, and the last class is unlimited, we coded the variable in three categories ("less than 2 million euro", "2-50 million euro, and "more than 50 million euro"). The mean of PO and GRAD for start-ups are 65.97 and 9.21, respectively; for the established firms, the means of the same variables are higher (69.39 and 9.63, respectively). $21 \%$ of start-ups and $20 \%$ of established firms belong to a group. Finally, this analysis observes that $21 \%$ and $18 \%$ of start-ups have benefited from special tax allowances and/or financial incentives supporting their investments, and financial incentives provided by the public sector, respectively; very similar percentages can be observed for established firms.

\subsubsection{Correlation Matrices}

Table 2 shows the values of the Bravais-Pearson correlation index for start-ups and established firms, respectively. For start-ups, there are positive linear correlations between INN_PRO and TURNOV (0.18), INN_PRO and EMPL (0.14), INN_PRO and GRAD (0.33). Apart from the obvious correlations between 
TURNOV and EMPL, the table shows interesting positive correlations between TURNOV and GRUOP (0.29), and EMPL and GROUP (0.43). Finally, there is an interesting negative correlation between PO and GRAD $(-0.20)$. Strangely, there are no significant correlations between INN_PRO and BEN_INV, or BEN_PUB.

For established firms, this study observes positive linear correlations between INN_PRO and TURNOV (0.24), INN_PRO and EMPL (0.15), INN_PRO and BEN_INV (0.09), INN_PRO and BEN_PUB (0.15), INN_PRO and GROUP (0.10), and INN_PRO and GRAD (0.11). Even for established companies, Table 2 displays a significant negative correlation between PO and GRAD (-0.07).

Table 2. Correlation matrices for start-ups and established firms

\begin{tabular}{|c|c|c|c|c|c|c|c|c|}
\hline \multicolumn{9}{|c|}{ START-UPS } \\
\hline \multirow{2}{*}{\multicolumn{9}{|c|}{ INN_PRO }} \\
\hline & & & & & & & & \\
\hline TURNOV & $0.18 * *$ & & & & & & & \\
\hline EMPL & $0.14 *$ & $0.51 * * *$ & & & & & & \\
\hline BEN_INV & 0.06 & 0.01 & 0.09 & & & & & \\
\hline BEN_PUB & 0.10 & -0.01 & 0.09 & $0.40 * * *$ & & & & \\
\hline GROUP & -0.03 & $0.29 * * *$ & $0.43 * * *$ & 0.09 & 0.05 & & & \\
\hline $\mathrm{PO}$ & -0.06 & -0.01 & -0.12 & -0.05 & 0.01 & $-0.14 *$ & & \\
\hline GRAD & $0.33 * * *$ & $0.21 * * *$ & $0.17 * *$ & 0.03 & 0.06 & 0.13 & $-0.20 * *$ & \\
\hline \multicolumn{9}{|c|}{ ESTALISHED FIRMS } \\
\hline & INN_PRO & TURNOV & EMPL & BEN_INV & BEN_PUB & GROUP & $\mathrm{PO}$ & GRAD \\
\hline \multicolumn{9}{|l|}{ INN_PRO } \\
\hline TURNOV & $0.24 * * *$ & & & & & & & \\
\hline EMPL & $0.15 * * *$ & $0.52 * * *$ & & & & & & \\
\hline BEN_INV & $0.09 * * *$ & $0.08 * * *$ & 0.01 & & & & & \\
\hline BEN_PUB & $0.15^{* * *}$ & 0.03 & 0.02 & $0.34 * * *$ & & & & \\
\hline GROUP & $0.10^{* * *}$ & $0.31 * * *$ & $0.33^{* * *}$ & $-0.05 * *$ & -0.01 & & & \\
\hline $\mathrm{PO}$ & -0.02 & -0.01 & $-0.04 *$ & $-0.04 *$ & 0.02 & 0.00 & & \\
\hline GRAD & $0.11 * * *$ & $0.07 * * *$ & 0.03 & 0.03 & $0.09 * * *$ & $0.15 * * *$ & $-0.07 * * *$ & \\
\hline
\end{tabular}

\subsection{Variable Selection}

The selection criterion for the independent variables is the "backward elimination" (Sparks et al. 1985). However, the stepwise regression has been also tested, based on the AIC criterion, but it led to the same predictors. This analysis considers, as depended variables, the innovation propensity (INN_PRO) at 2009 whereas the independent variables are collected in the period t-1, i.e. 2008.

\section{Methods and Results}

\subsection{Methods}

This analysis observes that in a sample of 2,283 European firms, almost half of these has not been characterized by product or process innovation in 2009. For this reason, this study examines the probability of creating innovation rather than analysing its intensity. Hence, linear probability models and logistic regression models, in which the dependent variable is binary ( 1 if the company has innovated, 0 otherwise), have been presented. Two reasons drive to use also the logistic model. First, it belongs to the family of generalized linear models (GLM), which are useful if the distribution of the response variable is different from the normal one. Because the distribution of INN_PRO is characterized by a high presence of null values, the logistic models is perfectly suited for this study. This analysis uses the R software with the "glm ()" command that is designed to perform generalized linear models (regressions) on binary outcome data, count data, probability data, given proportion and many other data types. The second reason for using also the logistic model is that this study may suppose that the relations between PO and INN_PRO, and GRAD and INN_PRO, are not linear; thus, this study aims to understand if the linear probability model can be considered a good approximation.

To test the hypotheses and analytically compare the effect of each variable between start-ups and established firms, this analysis adopts linear probability regression models and logistic regression models, simple slope analysis, and hypothesis testing on the comparison between regression coefficients. In addition, two 2SLS with multiple instrumental variables are computed to check for endogeneity. This study highlights that, we do not limit ourselves to consider a single regression model with a dummy variable to indicate the type of company, because this would have conducted to an aggregate effect of being star-up or established firm. Contrary, we are interested in comparing the effects of each single variable. An alternative possible solution would have been to consider a single regression model and an interaction term (dummy $\mathrm{x}$ variable) for each variable, but it had given 
a single regression model with too many variables and a consequent inevitable distortion and bad interpretation of some regression coefficients (of those variables without the interactions term). For this reason, this study considers two regression models and hypothesis tests to compare the individual regression coefficients although the sample size of the two types of company is different; effectively, no doubt arises on the fact that hypothesis testing on the comparison between regression coefficients of identical regression models applied on different samples considers sample size and variability. In the models used in this paper, the dependent variable is always INN_PRO at 2009 whereas the independent variables (at time t-1) are gradually added. Specifically, Models 1, 4, 7, and 10 are composed of control variables, Models 2, 5, 8, and 11 show the effect of GRAD and PO on INN_PRO, and Models 3, 6, 9, and 12 insert the interaction effect between technology push and demand pull. The final model (1) with the interaction effect takes the following functional form:

$$
++
$$

Because the variable TURNOV is categorical, two dummies have been provided for representing the three possible categories.

\section{Results}

\subsection{Start-ups' Regression Models}

Table 3 shows three linear probability regression models for start-ups. TURNOV, EMPL, GROUP and both types of benefit are not significant whereas GRAD and PO play key roles in both models 2 and 3 . The negative value of the coefficients of the interaction terms PO*GRAD is significant in model 3 underlining the strong moderating effect of PO on the relations between GRAD and INN_PRO. Table 5 displays the three logistic regression models for start-ups. These models confirm the results of the linear probability models, except for GROUP, which is significant in model 9.

Table 3. Linear probability regression models for start-ups

\begin{tabular}{|c|c|c|c|}
\hline & \multicolumn{3}{|c|}{ Dependent variable INN_PRO } \\
\hline & (1) & $(2)$ & (3) \\
\hline TURNOV_2 & $\begin{array}{l}0.101 \\
(0.087)\end{array}$ & $\begin{array}{l}0.098 \\
(0.084)\end{array}$ & $\begin{array}{l}0.063 \\
(0.084)\end{array}$ \\
\hline TURNOV_3 & $\begin{array}{l}0.423 \\
(0.381)\end{array}$ & $\begin{array}{l}0.178 \\
(0.373)\end{array}$ & $\begin{array}{l}0.229 \\
(0.369)\end{array}$ \\
\hline EMPL & $\begin{array}{l}0.0001 \\
(0.001)\end{array}$ & $\begin{array}{l}0.0001 \\
(0.001)\end{array}$ & $\begin{array}{l}0.00001 \\
(0.001)\end{array}$ \\
\hline BEN_INV & $\begin{array}{l}0.103 \\
(0.107)\end{array}$ & $\begin{array}{l}0.110 \\
(0.103)\end{array}$ & $\begin{array}{l}0.124 \\
(0.102)\end{array}$ \\
\hline BEN_PUB & $\begin{array}{l}-0.014 \\
(0.094)\end{array}$ & $\begin{array}{l}-0.015 \\
(0.090)\end{array}$ & $\begin{array}{l}0.004 \\
(0.090)\end{array}$ \\
\hline GROUP & $\begin{array}{l}0.135 \\
(0.097)\end{array}$ & $\begin{array}{l}0.133 \\
(0.095)\end{array}$ & $\begin{array}{l}0.153 \\
(0.095)\end{array}$ \\
\hline $\mathrm{PO}$ & & $\begin{array}{l}0.002^{*} \\
(0.001)\end{array}$ & $\begin{array}{l}0.004^{* * *} \\
(0.002)\end{array}$ \\
\hline GRAD & & $\begin{array}{l}0.008^{* * *} \\
(0.002)\end{array}$ & $\begin{array}{l}0.026^{* * *} \\
(0.009)\end{array}$ \\
\hline PO*GRAD & & & $\begin{array}{l}-0.0002^{* *} \\
(0.0001)\end{array}$ \\
\hline CONSTANT & $\begin{array}{l}0.429^{* * * *} \\
(0.072) \\
\end{array}$ & $\begin{array}{l}0.174 \\
(0.118) \\
\end{array}$ & $\begin{array}{l}-0.015 \\
(0.145) \\
\end{array}$ \\
\hline Observations & 159 & 159 & 159 \\
\hline $\mathrm{R}^{2}$ & 0.050 & 0.132 & 0.159 \\
\hline Adjusted $\mathrm{R}^{2}$ & 0.012 & 0.085 & 0.108 \\
\hline Residual Std. Error & $0.496(\mathrm{df}=152)$ & $0.477(\mathrm{df}=150)$ & $0.471(\mathrm{df}=149)$ \\
\hline F- Statistic & $1.328(\mathrm{df}=6 ; 152)$ & $2.842^{* * * *}(\mathrm{df}=8 ; 150)$ & $3.123^{* * * *}(\mathrm{df}=9 ; 149)$ \\
\hline
\end{tabular}

Note. $* * *$ Significance codes .01; ** Significance codes .05.; * Significance codes .1 


\subsection{Established Firms' Regression Models}

Table 4 reports three linear probability regression models for established firms. The results are very different from those of start-ups; indeed, TURNOV, EMPL, GROUP, and BEN_PUB have a significant positive effect on INN_PRO. GRAD has a positive impact on INN_PRO but PO and the interaction term are not significant in model 6. Also, in this context, Table 6, which shows the logistic regression models for established firms, confirms the goodness of all the results of the linear probability regression models. However, PO, which is weakly significant in Model 11, loses its significance in Model 12.

Table 4. Linear probability regression models for established firms

Dependent variable INN_PRO

(4)

$\begin{array}{ll}\text { TURNOV_2 } & 0.189^{* * *} \\ & (0.024) \\ \text { TURNOV_3 } & 0.229^{* * *} \\ & (0.067) \\ \text { EMPL } & 0.001^{* * *} \\ & (0.0002) \\ \text { BEN_INV } & 0.042 \\ & (0.026) \\ \text { BEN_PUB } & 0.124^{* * *} \\ & (0.027) \\ \text { GROUP } & 0.0004 \\ & (0.025)\end{array}$

PO

GRAD

PO*GRAD

CONSTANT

0.428
$(0.020)$

$\begin{array}{ll}\text { Observations } & 2,124 \\ \mathrm{R}^{2} & 0.087 \\ \text { Adjusted } \mathrm{R}^{2} & 0.084 \\ \text { Residual Std. Error } & 0.456(\mathrm{df}=2117) \\ \text { F -Statistic } & 33.567^{* * *} \\ & (\mathrm{df}=6 ; 2117)\end{array}$

(5)

(6)

$\begin{array}{ll}0.185^{* * *} & 0.185^{* * *} \\ (0.024) & (0.024) \\ & 0.214^{* * *} \\ 0.214^{* * *} & (0.067) \\ (0.067) & 0.001^{* * *} \\ & (0.0002) \\ 0.001^{* * *} & \\ (0.0002) & 0.040 \\ 0.040 & (0.025) \\ (0.025) & 0.111^{* * *} \\ 0.111^{* * *} & (0.027) \\ (0.027) & \\ & -0.011 \\ -0.011 & (0.025) \\ (0.025) & \\ & 0.001 \\ 0.001^{*} & (0.0004) \\ (0.0003) & \\ 0.004^{* * *} & 0.004^{* * *} \\ (0.001) & (0.001) \\ & -0.00000 \\ & (0.00002) \\ 0.355^{* * *} & 0.355^{* * *} \\ (0.030) & (0.034) \\ & \\ & \\ & \\ & \\ & \\ & \\ & \\ & \\ & \\ & \end{array}$

$\begin{array}{ll}2,124 & 2,124 \\ 0.100 & 0.100 \\ 0.097 & 0.096 \\ 0.453(\mathrm{df}=2115) & 0.453(\mathrm{df}=2114) \\ 29.393^{* * *} & 26.114^{* * *} \\ (\mathrm{df}=8 ; 2115) & (\mathrm{df}=9 ; 2114)\end{array}$

Note. *** Significance codes .01; ** Significance codes .05.; * Significance codes .1

\subsection{Robustness Testing}

A major challenge in empirical research is to limit the problem of endogeneity. Endogeneity is mainly due to omitted variables and simultaneity. To tackle this problem, a common practice relies on estimates of instrumental variables or/and lagging by one period the right-hand side endogenous variable. To consider the possible concerns due to endogeneity, this refers to both these methods. First, this study reduces the possible impact of reverse causality by adopting a dependent variable which is taken at time t whereas the independent variables are captured at time t-1. Second, this study considers that GRAD and PO may be suspected to be endogenous in our models; thus, this analysis controlled the potential for endogeneity in our final regression models with the interactions terms, by using a two-stage least squares (2SLS) with multiple instrumental variables, using the R package "AER" with the function "ivreg". Instrumental variables are used to compute estimated values of the problematic predictors (GRAD and PO) in the first stage, and then those computed values are used to estimate a 
regression model of the dependent variable (INN_PRO) in the second stage. However, to be effective (i.e., not weak) an instrumental variable should not be correlated with the dependent variable(s) predicted in the second stage but should be correlated with the potential endogenous variable(s) predicted in the first stage. This study identifies a set of variables that meet these requirements (e.g. the type of the CEO, the gender of the CEO, if the CEO is a member of the controlling family). Despite the present attempt, 2SLS approach with data yielded similar results to the ordinary least squares approach and showed that endogeneity was not a concern in our study. Indeed, for each of the final models, we were forced to accept the null hypothesis that the OLS model is equal to the 2SLS-IV. Specifically, for the models of start-ups we got no weak instruments with the Wu-Hausman p-values equal to 0.002 (PO), 0.047 (GRAD), and 0.021 (PO*GRAD), Wu-Hausman p-value equal to 0.045 , and the Sargan p-value equal to 0.712 . For the models of established firms, the analysis got no weak instruments with the Wu-Hausman p-values equal to 2e-16 (PO), 0.001 (GRAD), and 1.84e-14 (PO*GRAD), Wu-Hausman p-value equal to $5.93 \mathrm{e}-15$, and the Sargan p-value equal to 0.836 .

Table 5. Logistic regression models for start-ups Dependent variable INN_PRO

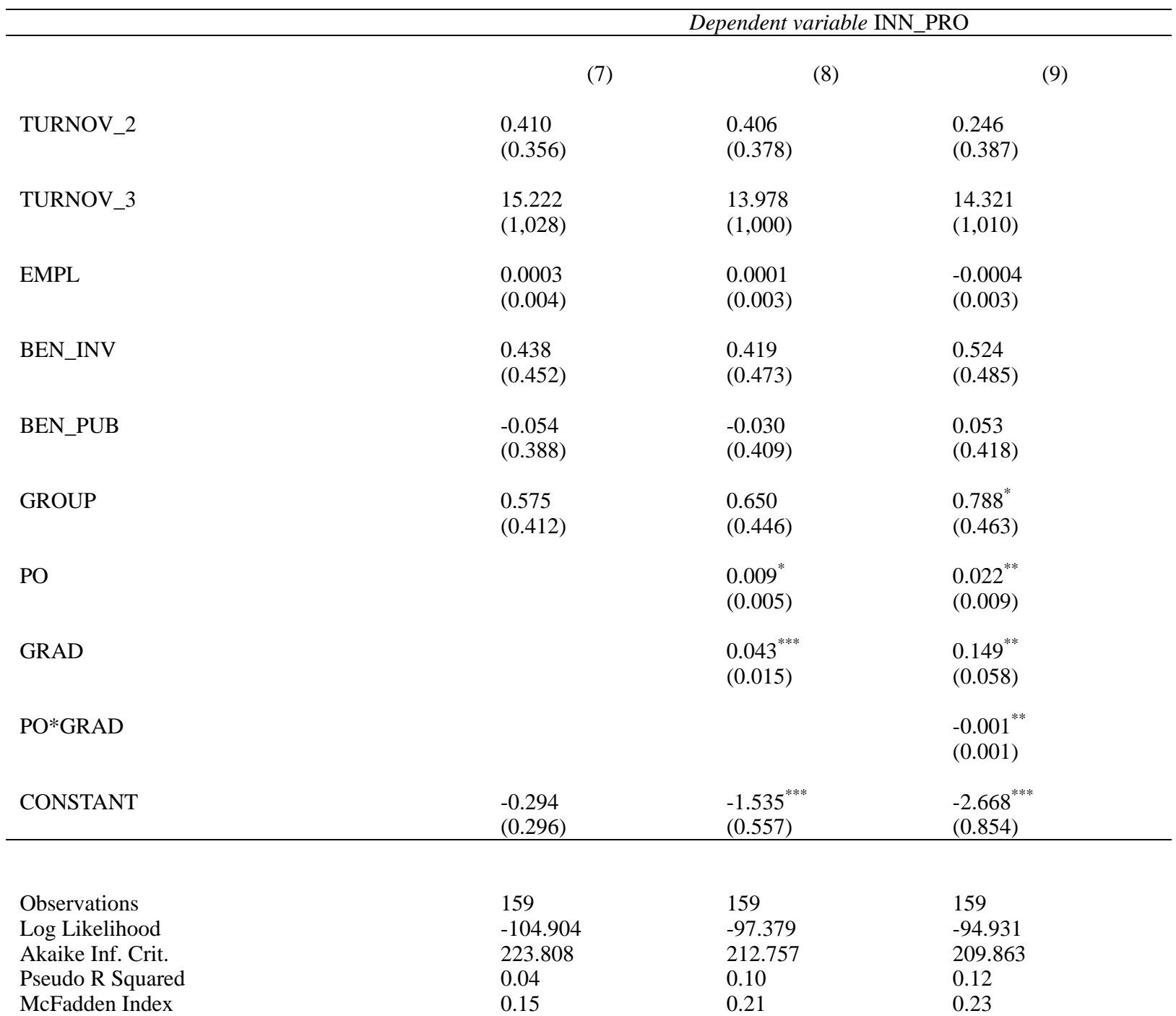

Note. *** Significance codes .01;** Significance codes .05.; * Significance codes .1

\subsection{Simple Slope Analysis}

To better understand the intensity of the interactions and to examine the consistency of that direction throughout the range of PO, the simple slope analyses (Aiken and West, 1991) was conducted. Figure 1 shows the strong role of the firms' turnover made up by sales of produced-to-order goods in moderating the effect of the university graduates in the workforce of start-ups on the innovation propensity. The analysis observes that, for low level of PO, the impact of GRAD on INN_PRO increases (the angular coefficient is largest).

Figure 2 displays the weak role of the firms' turnover made up by sales of produced-to-order goods in 
moderating the effect of the university graduates in the workforce of Established Firms on INN_PRO. This paper highlights that, in established firms, the moderating role of PO is not significant (as shown also in Table 4).

\subsection{Hypotheses Checks}

Table 7 shows that both hypotheses H1.a and H1.b can be accepted because the stock of qualified human capital positively affects the innovation propensity both in young and mature specialized suppliers. However, hypothesis H1.c should be refused because the coefficient of GRAD in start-ups is greater than that one of established firms; the test for differences between slopes of the two models confirms that this difference is significant.

Also hypotheses H2.a and H2.b can be accepted because the sales of produced-to order goods positively affect the innovation propensity both in young and mature specialized suppliers. In this case, the hypothesis on comparison (H1.c) can be accepted because the coefficient of PO in start-ups is greater than that one of established firms; the test for differences between slopes also proves that this difference is significant.

With regard to the interaction effects, this study observes that hypothesis H3.a is not supported; indeed, because the relationship between the stock of qualified human capital and the innovation propensity of the young specialized suppliers is negatively moderated by the sales of produced-to order goods. Thus, increased levels of sales of produced-to order goods decrease the contribution of the qualified human capital to innovation propensity.

Table 6. Logistic regression models for established firms

Dependent variable INN_PRO

(10)

$0.749^{* * *}$
$(0.110)$

TURNOV_2

TURNOV_3

EMPL

BEN_INV

BEN_PUB

GROUP

PO

GRAD

PO*GRAD
$1.314^{* * * *}$

(0.440)

$0.005^{* * *}$

(0.001)

$0.212^{*}$

$(0.127)$

$0.670^{* * * *}$

(0.142)

$-0.021$

$(0.123)$
(11)

$0.731^{* * * *}$

(0.111)

$1.197^{* * * *}$

(0.444)

$0.006^{* * * *}$

$(0.001)$

0.198

(0.129)

$0.605^{* * * *}$

(0.143)

$-0.080$

$(0.125)$

0.002

(0.002)

$0.021^{* *}$

(0.008)

0.00002

$(0.0001)$

$-0.737^{* * *}$

(0.166)

\begin{tabular}{llll} 
Observations & 2,124 & 2,124 & 2,124 \\
Log Likelihood & $-1,271.874$ & $-1,255.034$ & $-1,255.007$ \\
Akaike Inf. Crit. & $2,557.748$ & $2,528.067$ & $2,530.014$ \\
Pseudo R Squared & 0.07 & 0.08 & 0.09 \\
McFadden Index & 0.20 & 0.214 & 0.215 \\
\hline
\end{tabular}

Note. *** Significance codes .01 ; ** Significance codes .05.; * Significance codes .1 


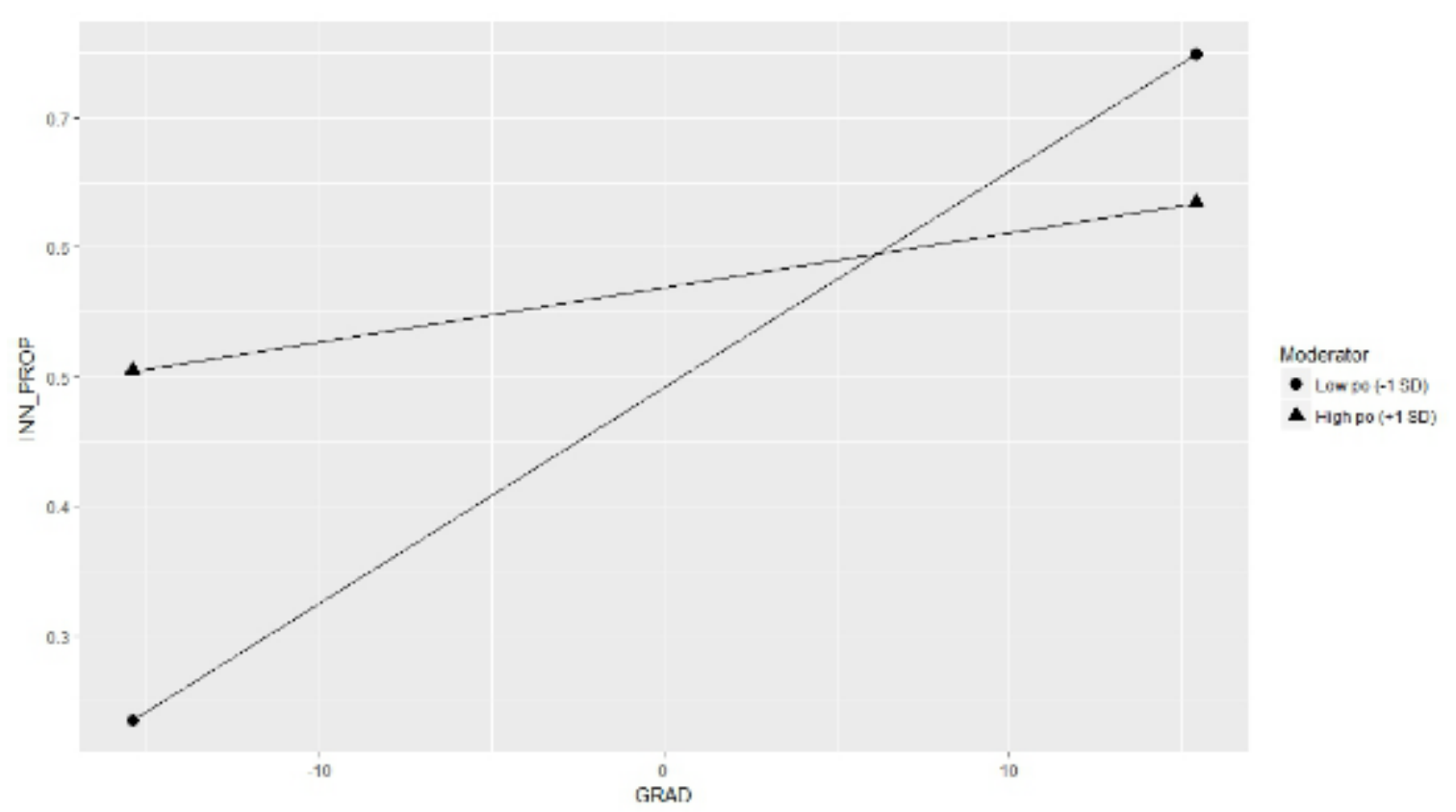

Figure 1. The strong role of firms' turnover made up by sales of produced-to-order goods in moderating the effect of the university graduates in the workforce of start-ups on innovation propensity

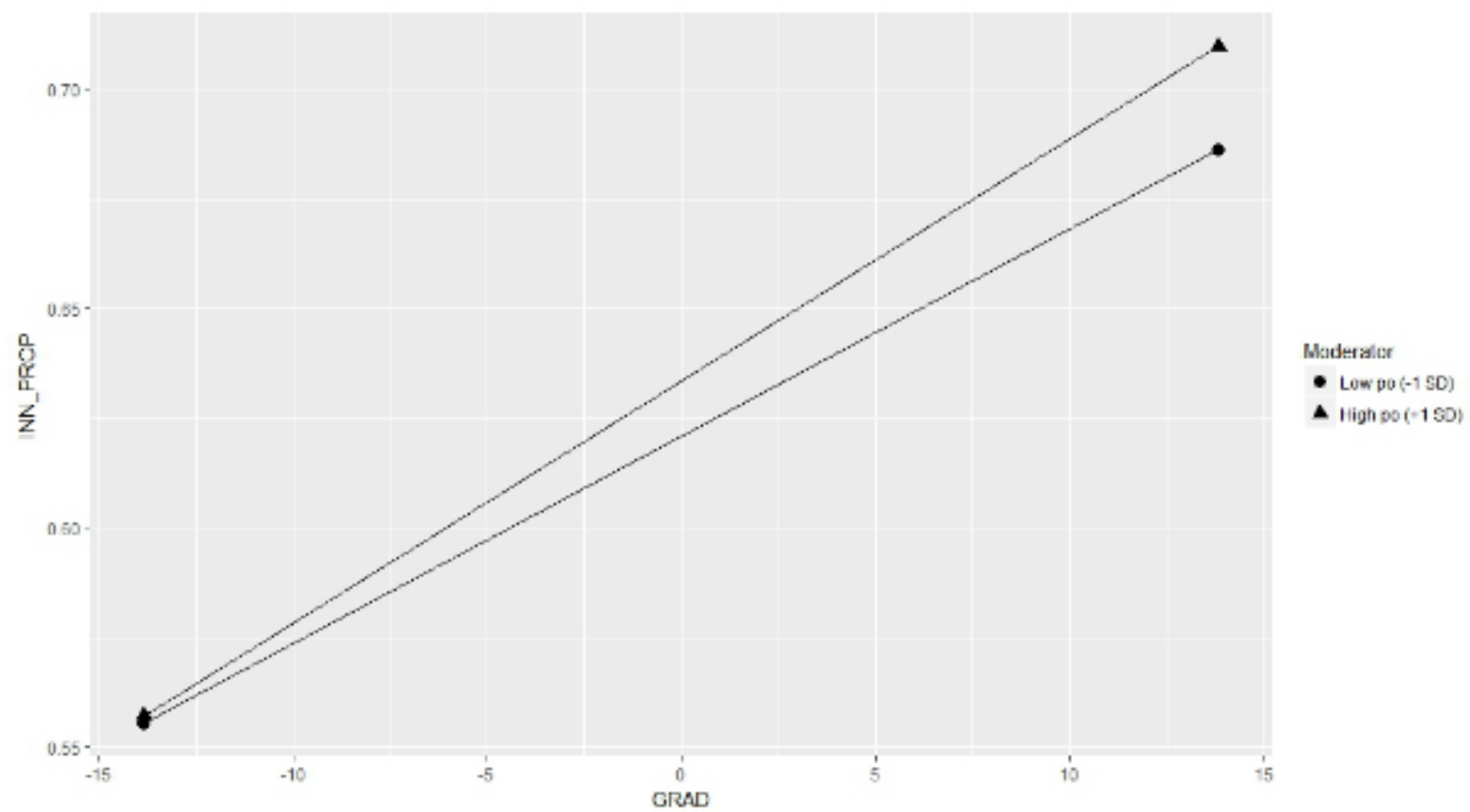

Figure 2. The weak role of firms' turnover made up by sales of produced-to-order goods in moderating the effect of the university graduates in the workforce of established firms on innovation propensity

On the contrary, hypothesis H3.b should be refused because, in established firms, the interaction term is not significant. Therefore, hypotheses H3.c should be refused even if the test for differences between slopes of the two models confirms that this difference is significant. Indeed, the moderating role played by the percentage of the turnover made up by sales of produced-to order goods in the relationship between the percentage of university graduates in the workforce and innovation propensity of the specialized suppliers is more intense for start-ups than for established firms. However, according to the development of our hypotheses H3.a and H3b, and finally $\mathrm{H} 3 \mathrm{c}$, a stronger positive effect of the interaction term in start-up has been expected, but instead the sign of the coefficient is negative. 
Table 7. Check of hypotheses and summary information

\begin{tabular}{|c|c|c|}
\hline Hypothesis & Result & Tests for differences between slopes of two models \\
\hline Hypothesis 1.a & TRUE & \\
\hline Hypothesis $1 . b$ & TRUE & \\
\hline Hypothesis $1 . c$ & FALSE & $\begin{array}{l}\text { Significant differences for both linear ( } p \text {-value }=0.0112 \text { ) and non-linear } \\
\text { models ( } p \text {-value }=0.0287 \text { ) but it is more intense for start-ups }\end{array}$ \\
\hline Hypothesis 2.a & TRUE & \\
\hline Hypothesis $2 . b$ & TRUE & \\
\hline Hypothesis 2.c & TRUE & $\begin{array}{l}\text { Significant differences for both linear }(p \text {-value }=0.0189) \text { and non-linear } \\
\text { models }(p \text {-value }=0.0287)\end{array}$ \\
\hline Hypothesis 3.a & FALSE & The interaction term is negative and significant. \\
\hline Hypothesis 3.b & FALSE & The interaction term is not significant in Models IV and VI. \\
\hline Hypothesis 3.c & FALSE & $\begin{array}{l}\text { Significant differences for both linear }(\mathrm{p} \text {-value }=0.0321) \text { and non-linear } \\
\text { models ( } \mathrm{p} \text {-value }=0.0476) \text { but we expected that the interaction term for } \\
\text { the start-ups models was more positive that that one of established firms }\end{array}$ \\
\hline
\end{tabular}

\section{Discussion and Conclusions}

The results demonstrate that both the technology and demand determinants exert a positive impact in both start-ups and established firms, even if, in established firms, the demand determinant is less significant, and the technology determinant exerts a weaker effect. Moreover, in the investigation of the interactions terms, this study highlights that only one is statistically significant; indeed, in start-ups, there is a significant moderating role played by the percentage of the turnover made up by sales of produced-to order goods on the relationship between the percentage of university graduates in the workforce and innovation propensity. Therefore, for start-ups, this study shows that low percentages of the turnover made up by sales of produced-to order goods strongly potentiate the positive effect of the percentage of university graduates in the workforce on the start-ups' innovation propensity whereas, for high percentages of the turnover made up by sales of produced-to order goods, this influence is weaker.

This paper brings to light three important findings concerning the technology and demand issues considered both in isolation and in their interaction. First, in addition to confirming, for both young and mature firms, the importance of technology as a source of innovation, this paper demonstrates that, regarding the innovation propensity, the stock of graduated human capital is more relevant for start-ups than for established firms. This result could be explained arguing that in established firms the level of education is less representative of the firm's technological capabilities because people's experience and acquired skills tend to be more relevant in undertaking technological trajectories.

Second, the demand effect demonstrates that market conditions are more relevant for the young specialized suppliers, so that firm's age is an important factor conditioning the intensity of the demand pulled investments in innovation. This result strengthens those studies arguing that sales and cash flow should be more crucial in inducing and financing innovation projects in liquidity-constrained firms (Goodacre and Tonks, 1995; Hall et al., 1999; O'Sullivan, 2005; Piva and Vivarelli, 2007). The weaker demand effect for mature firms could be a signal of a greater availability of other financial sources of innovation combined with the absence of necessity to explore new market opportunities.

Third, the moderating role exerted by the sales of produced-to-order goods on the relationship between the stock of qualified human capital and the start-ups' innovation propensity demonstrates that technology on one side and demand on the other are not always the best companions in pushing investments in innovation. In the young specialized suppliers, high levels of the demand determinant weaken the positive effect of the technology determinant so that the former does not reinforce the latter. A possible explanation for that is that high percentages of turnover signal to the firm the achievement of the desired market share with a resulting slowdown of the striving to explore new technological opportunities.

This paper contributes to the recent literature about technology push and demand-pull policies (Costantini et al., 2015; Nemet, 2009; Peters et al., 2012) and contributes in making managers operating in the specialized suppliers' industry more aware of the global effect that some choices concerning the composition of the firm's workforce may produce on the firm's innovation propensity. Specifically, they need to consider that the effect on the firm's innovation propensity produced by an increase of the percentage of university graduates in the workforce in start-ups with high percentages of the turnover made up by sales of produced-to order goods is weakened by the interaction between the two determinants.

Moreover, findings have implications for policy makers who take action to support firms' innovation because an overemphasis on demand pull oriented policies for start-ups may be counterproductive. 
There are significant limitations to this study. First, this study considers only European countries; thus, it is not possible to know if the results can be extended to other countries, such as United States and emerging countries. Second, a panel data analysis and the consideration of expected demand would have been more interesting but the EFIGE database do not allow us to perform this type of analysis.

Several questions that require investigation emerge from this study. For example, it would be useful for future research to determine whether our results are still valid in temporal and industry scenarios different from those we investigated.

Given the overwhelming size of the services sector in modern industrial economies, future comparison between start-ups and established firms should focus on the service industries to have a complete view of the relationship between age and technology/demand determinants of innovation propensity. There are also other important implications of this study. In particular, and in a more interpretative fashion, the above findings can be considered as uncovering other potential venues for future research. First, by considering other variables expressing the technology and demand determinants, more comprehensive interaction patterns might emerge.

Second, the start-ups' interaction pattern paves the way for further investigations concerning the inner dynamics between the signalling role young firms attribute to an increasing market demand and their technological attitude towards innovation.

\section{References}

Acs, Z. J., \& Audretsch, D. B. (1991). R\&D, Firm Size and Innovative Activity, In Acs, Z.J. and Audretsch, D.B. (Ed.), Innovation and Technological Change (pp. 39-59). London, Harvester Wheatsheaf. https://doi.org/10.3998/mpub.12958

Acs, Z. J., Audretsch, D. B., \& Feldman, M. P. (1994). R\&D Spillovers and Recipient Firm Size. Review of Economics and Statistics, 76(2), 336-339. https://doi.org/10.2307/2109888

Aiken, L. S., \& West, S. G. (1991). Multiple Regression: Testing and Interpreting Interactions. Sage Publications.

Altomonte, C., \& Aquilante, T. (2012). The Eu-Efige/Bruegel-Unicredit Dataset. Working Paper. Bruegel.

Archibugi, D. (2001). Pavitt's Taxonomy Sixteen Years On: A Review Article. Economics of Innovation and New Technology, 10(5), 415-425. https://doi.org/10.1080/10438590100000016

Archibugi, D., \& Pianta, M. (1996). Measuring Technological Change through Patents and Innovation Surveys. Technovation, 16(9), 451-468. https://doi.org/10.1016/0166-4972(96)00031-4

Archibugi, D., Filippetti, A., \& Frenz, M. (2013). The impact of the economic crisis on innovation: Evidence from Europe. Technological Forecasting and Social Change, 80(7), 1247-1260. https://doi.org/10.1016/j.techfore.2013.05.005

Arthur, W. B. (2007). The structure of invention. Research Policy, 36(2), 274-287. https://doi.org/10.1016/j.respol.2006.11.005

Audretsch, D. B., \& Vivarelli, M. (1996). Firm size and R\&D spillovers: Evidence from Italy. Small Business Economics, 8(3), 249-258. https://doi.org/10.1007/BF00388651

Balasubramanian, N., \& Lee, J. (2008). Firm age and innovation. Industrial and Corporate Change, 17(5), 1019-1047. https://doi.org/10.1093/icc/dtn028

Balss, A. A., \& Yosha, O. (2003). Financing R\&D in mature companies: an empirical analysis. Economics of Innovation and New Technology, 12(5), 425-447. https://doi.org/10.1080/1043859022000029249

Barge-Gil, A., \& López, A. (2014). R\&D determinants: Accounting for the differences between research and development. Research Policy, 43(9), 1634-1648. https://doi.org/10.1016/j.respol.2014.04.017

Baysinger, B. D., \& Hoskinsson, R. E. (1989). Diversification strategy and R\&D intensity in multiproduct firms. Academy of Management Journal, 32(2), 310-332.

Berger, A., \& Udell, G. (2002). Small business credit availability and relationship lending: The importance of bank organizational structure. Economic Journal, 112(477), 32-53. https://doi.org/10.1111/1468-0297.00682

Blalock, H. M. (1961). Evaluating the relative importance of variables. American Sociological Review, 26, 866-874. https://doi.org/10.2307/2090571

Braga, H., \& Willmore, L. (1991). Technological imports and technological effort: an analysis of their determinants in Brazilian firms. The Journal of Industrial Economics, 39(4), 421-332. 
https://doi.org/10.2307/2098441

Brouwer, E., \& Kleinknecht, A. (1996). Firm size, small business presence and sales of innovative products: A micro-econometric analysis. Small Business Economics, 8(3), 189-201. https://doi.org/10.1007/BF00388647

Buchuk, D., Larrain, B., Muñoz, F., \& Urzúa, F. (2014). The internal capital markets of business groups: Evidence from intra-group loans. Journal of Financial Economics, 112(2), 190-212. https://doi.org/10.1016/j.jfineco.2014.01.003

Bush, V. (1945). As We May Think - Vannevar Bush - The Atlantic. The Atlantic, 101-108.

Cantista, I., \& Tylecote, A. (2008). Industrial innovation, corporate governance and supplier-customer relationships. Journal of Manufacturing Technology Management, 19(5), 576-590. https://doi.org/10.1108/17410380810877267

Cecere, G., \& Corrocher, N. (2016). Stringency of regulation and innovation in waste management: an empirical analysis on EU countries. Industry and Innovation, 23(7), 625-646. https://doi.org/10.1080/13662716.2016.1195253

Chandy, R. K., \& G. L. Tellis (2000). 'The incumbent's curse. Incumbency, size, and radical product innovation', Journal ofMarketing, 64, 1-17.

Chidamber, S., \& Kon, H. B. (1994). A Research Retrospection on Innovation Inception and Success: The Technology-Push Demand-Pull Question. International Journal of Technology Management, 9(1), 94-112.

Christensen, C. M., Bohmer, R., \& Kenagy, J. (2000). Will disruptive innovations cure health care? Harvard Business Review, 78(5), 102-112.

Coad, A., \& Rao, R. (2008). Innovation and firm growth in high-tech sectors: A quantile regression approach. Research Policy, 37(4), 633-648. https://doi.org/10.1016/j.respol.2008.01.003

Cohen, W. M., \& Klepper, S. (1996). A reprise of size and R\&D. Economic Journal, 106, 925-951. https://doi.org/10.2307/2235365

Cohen, W. M., \& Levinthal, D. A. (1990). Absorptive Capacity: A New Perspective on Learning and Innovation. Administrative Science Quarterly, 35(1), 128. https://doi.org/10.2307/2393553

Costantini, V., Crespi, F., Martini, C., \& Pennacchio, L. (2015). Demand-pull and technology-push public support for eco-innovation: The case of the biofuels sector. Research Policy, 44(3), 577-595. https://doi.org/10.1016/j.respol.2014.12.011

Crepon, B., Duguet, E., \& Mairesse, J. (1998). Research, innovation, and productivity an econometric analysis at the firm level. Economics of Innovation and New Technology, 7(2), 115-158. https://doi.org/10.1080/10438599800000031

Criscuolo, P., Nicolaou, N., \& Salter, A. (2012). The elixir (or burden) of youth? Exploring differences in innovation between start-ups and established firms. Research Policy, 41(2), 319-333. https://doi.org/10.1016/j.respol.2011.12.001

Czarnitzki, D., \& Hottenrott, H. (2011). R\&D investment and financing constraints of small and medium-sized firms. Small Business Economics, 36(1), 65-83. https://doi.org/10.1007/s11187-009-9189-3

Czarnitzki, D., \& Lopes-Bento, C. (2014). Innovation subsidies: Does the funding source matter for innovation intensity and performance? Empirical evidence from Germany. Industry and Innovation, 21(5), 380-409. https://doi.org/10.1080/13662716.2014.973246

Damanpour, F. (2010). An integration of research findings of effects of firm size and market competition on product and process innovations. British Journal of Management, 21(4), 996-1010. https://doi.org/10.1111/j.1467-8551.2009.00628.x

D'Este, P., Rentocchini, F., \& Vega-Jurado, J. (2014). The role of human capital in lowering the barriers to engaging in innovation: evidence from the Spanish innovation survey. Industry and Innovation, 21(1), 1-19. https://doi.org/10.1080/13662716.2014.879252

Di Stefano, G., Gambardella, A., \& Verona, G. (2012). Technology push and demand pull perspectives in innovation studies: Current findings and future research directions. Research Policy, 41(8), 1283-1295. https://doi.org/10.1016/j.respol.2012.03.021

Doloreux, D., Shearmur, R., \& Rodriguez, M. (2016). Determinants of R\&D in knowledge-intensive business 
services firms. Economics of Innovation and New Technology, 25(4), 391-405. https://doi.org/10.1080/10438599.2015.1067001

Dosi, G. (1982). Technological paradigms and technological trajectories. A suggested interpretation of the determinants and directions of technical change. Research Policy, 11(3), 147-162. https://doi.org/10.1016/0048-7333(82)90016-6

Franke, N., \& Von Hippel, E. (2003). Satisfying heterogeneous user needs via innovation toolkits: The case of Apache security software. Research Policy, 32(7), 1199-1215.

https://doi.org/10.1016/S0048-7333(03)00049-0

Frankel, M. (1955). Obsolescence and technological change in a maturing economy. American Economic Review, 45(3), 296-319.

Freeman, C. (1974). The Economics of Industrial Innovation. The MIT Press: Cambridge MA.

Freeman, C. (1994). The economics of technical change. Cambridge Journal of Economics, 463-514. https://doi.org/10.1093/oxfordjournals.cje.a035286

Freeman, C., \& Soete, L. (1997). The Economics of Industrial Innovation. The MIT Press: Cambridge MA.

Freeman, C., \& Louca, F. (2001). As Time Goes By: From the Industrial Revolutions to the Information Revolution. Oxford University Press: Oxford.

Fritsch, M., \& M. Meschede (2001). 'Product innovation, process innovation, and size'. Review of Industrial Organiza-tion, 19, 335-350. https://doi.org/10.1023/A:1011856020135

Fritsch, M., Brixy, U., \& Falck, O. (2006). The effect of industry, region and time on new business survival - a multi-dimensional analysis. Review of Industrial Organization, 28(3), 285-306. https://doi.org/10.1007/s11151-006-0018-4

Gehringer, A. (2010). Pecuniary Knowledge Externalities in: New Taxonomy: Knowledge Interactions in a Vertically Integrated System. Discussion Paper 102, George August Universitat Gottingen.

Gelman, A. (2007). Scaling regression inputs by dividing by two standard deviations. Statistics in Medicine, 27(15), 2865-2873. https://doi.org/10.1002/sim.3107

Ghisetti, C. (2017). Demand-pull and environmental innovations: Estimating the effects of innovative public procurement. Technological forecasting and social change, 125, 178-187. https://doi.org/10.1016/j.techfore.2017.07.020

Goodacre, A., \& Tonks, I. (1995). Finance and Technological Change. In Stoneman, P. (Ed.), Handbook of the Economics of Innovation and Technical Change. Oxford, Blackwell, 298-341.

Gopalan, R., Nanda, V., \& Seru, A. (2007). Affiliated firms and financial support: evidence from Indian business groups. Journal of Financial Economics, 86(3), 759-795. https://doi.org/10.1016/j.jfineco.2006.09.008

Guzzini, E., \& Iacobucci, D. (2014). Business group affiliation and R\&D. Industry and Innovation, 21(1), 20-42. https://doi.org/10.1080/13662716.2014.879253

Hall, B. H. (1992). Investment and Research and Development at the Firm Level: Does the Source of Financing Matter? NBER Working Paper 4096.

Hall, B. H. (2005). The financing of innovation. In Shane, S. (Ed.). Handbook of technology management. Oxford: Blackwell Publishers.

Hall, B. H., Mairesse, J., Branstetter, L., \& Crepon, B. (1998). Does Cash Flow Cause Investment and R\&D? An Exploration Using Panel Data for French, Japanese, and United States Scientific Firms. SSRN Working paper 98/11, 129-156.

Harhoff, D. (1997). Are there financing constraints for R\&D and investment in German manufacturing firms?. WZB Discussion Paper FS IV, 97-145.

Harhoff, D., Henkel, J., \& Von Hippel, E. (2003). Profiting from voluntary information spillovers: How users benefit by freely revealing their innovations. Research Policy, 32(10), 1753-1769. https://doi.org/10.1016/S0048-7333(03)00061-1

Higuchi, Y., Nam, V. H., \& Sonobe, T. (2015). Sustained impacts of Kaizen training. Journal of Economic Behavior \& Organization, 120, 189-206. https://doi.org/10.1016/j.jebo.2015.10.009

Himmelberg, C. P., \& Petersen, B. C. (1994). R\&D and Internal Finance: A Panel Study of Small Firms in 
High-Tech Industries. Review of Economics and Statistics, 76, 38-51. https://doi.org/10.2307/2109824

Hofheinz, P. (2009). EU 2020: why skills are key for Europe's future. Policy Brief, 4(1), 1-23.

Horbach, J. (2008). Determinants of environmental innovation-New evidence from German panel data sources. Research Policy, 37(1), 163-173. https://doi.org/10.1016/j.respol.2007.08.006

Iansiti, M., \& MacCormack, A. (1997). Developing products on Internet time. Harvard Business Review, 75(5), 108-117.

Irwin, D. A., \& Klenow, P. J. (1996). High-tech R\&D subsidies Estimating the effects of Sematech. Journal of International Economics, 40(3), 323-344. https://doi.org/10.1016/0022-1996(95)01408-X

Katila, R., \& Shane, S. (2005). When does lack of resources make new firms innovative? Academy of Management Journal, 48(5), 814-829. https://doi.org/10.5465/amj.2005.18803924

Khanna, T., \& Yafeh, Y. (2005). Business groups and risk sharing around the world. Journal of Business, 78(1), 301-340. https://doi.org/10.1086/426527

Kline, S., \& Rosenberg, N. (1986). An overview of innovation. In Landau, R. and Rosenberg, N. (Ed.). The Positive Sum Strategy. Academy of Engineering Press: Washington.

Lakhani, K. R., \& Von Hippel, E. (2003). How open source software works: "free" user-to-user assistance. Research Policy, 32(6), 923-943. https://doi.org/10.1016/S0048-7333(02)00095-1

Langlois, R. N., \& Robertson, P. L. (1992). Networks and innovation in a modular system: Lessons from the microcomputer and stereo component industries. Research Policy, 21(4), 297-313. https://doi.org/10.1016/0048-7333(92)90030-8

Lee, C. Y. (2003). A simple theory and evidence on the determinants of firm R\&D. Economics of Innovation and New Technology, 12(5), 385-395. https://doi.org/10.1080/1043859022000003418

Levin, R. C., Klevorick, A. K., Nelson, R. R., \& Winter, S. G. (1987). Appropriating the Returns from Industrial Research and Development; Comments and Discussion. Brookings Papers on Economic Activity, 3, 783. https://doi.org/10.2307/2534454

Liu, X., \& Buck, T. (2007). Innovation performance and channels for international technology spillovers: Evidence from Chinese high-tech industries. Research Policy, 36(3), 355-366. https://doi.org/10.1016/j.respol.2006.12.003

Lubik, S., Lim, S., Platts, K., \& Minshall, T. (2012). Market-pull and technology-push in manufacturing start-ups in emerging industries. Journal of Manufacturing Technology Management, 24(1), 10-27. https://doi.org/10.1108/17410381311287463

Lundvall, B. A., \& Johnson, B. (1994). The Learning Economy. Journal of Industry Studies, 1(2), 23-42. https://doi.org/10.1080/13662719400000002

Malerba, L. (2004). Sectoral systems of Innovation. Cambridge University Press: Cambridge, UK. https://doi.org/10.1017/CBO9780511493270

Malerba, F., \& Orsenigo, L. (1997). Technological regimes and sectoral patterns of innovation. Industrial and Corporate Change, 6(1), 83-117. https://doi.org/10.1093/icc/6.1.83

March, J. G. (1991). Exploration and exploitation in organizational learning. Organization Science, 2(1), 71-87. https://doi.org/10.1287/orsc.2.1.71

McGuirk, H., Lenihan, H., \& Hart, M. (2015). Measuring the impact of innovative human capital on small firms' propensity to innovate. Research Policy, 44(4), 965-976. https://doi.org/10.1016/j.respol.2014.11.008

Mohnen., P., \& Röller, L. H. (2005). Complementarities in innovation policy. European Economic Review, 49(6), 1431-1450. https://doi.org/10.1016/j.euroecorev.2003.12.003

Monreal-Pérez, J., Aragón-Sánchez, A., \& Sánchez-Marín, G. (2012). A longitudinal study of the relationship between export activity and innovation in the Spanish firm: The moderating role of productivity. International Business Review, 21(5), 862-877. https://doi.org/10.1016/j.ibusrev.2011.09.010

Morrison, P. D., Roberts, J. H., \& Von Hippel, E. (2000). Determinants of user innovation and innovation sharing in a local market. Management Science, 46(12), 1513-1527. https://doi.org/10.1287/mnsc.46.12.1513.12076

Mowery, D. C. (1983). Economic theory and government technology policy. Policy Sciences, 16(1), 27-43. https://doi.org/10.1007/BF00138466 
Mowery, D., \& Rosenberg, N. (1979). The influence of market demand upon innovation: a critical review of some recent empirical studies. Research Policy, 8(2), 102-153. https://doi.org/10.1016/0048-7333(79)90019-2

Muller, E., \& Zimmermann, V. (2009). The importance of equity finance for R\&D activity. Small Business Economics, 33(3), 303-318. https://doi.org/10.1007/s11187-008-9098-x

Mulkay, B., Hall, B., \& Mairesse, J. (2001). Investment and R\&D in France and in the United States. In Bundesbank, D. (Ed.). Investing today for the world of tomorrow. Germany: Springer Verlag. https://doi.org/10.1007/978-3-642-56601-1_19

Myers, S., \& Marquis, D. (1969). Successful industrial innovation: a study of factors underlying innovation in selected firms. National Science Foundation, 69-117.

Nambisan, S. (2002). Designing Virtual Customer Environments for NPD Product Development: Toward a Theory. Academy of Management Review, 27(3), 329-413. https://doi.org/10.5465/amr.2002.7389914

Nelson, R. R., \& Winter, S. G. (1977). In search of useful theory of innovation. Research Policy, 6(1), 36-76. https://doi.org/10.1016/0048-7333(77)90029-4

Nemet, G. F. (2009). Demand-pull, technology-push, and government-led incentives for non-incremental technical change. Research Policy, 38(5), 700-709. https://doi.org/10.1016/j.respol.2009.01.004

Nieto, M. J., \& Santamaría, L. (2010). Technological collaboration: Bridging the innovation gap between small and large firms. Journal of Small Business Management, 48(1), 44-69. https://doi.org/10.1111/j.1540-627X.2009.00286.x

O’Sullivan, M. (2005). Finance and Innovation. In Fagerberg, J., Mowery, D.C., \& Nelson, R.R. (Ed.), The Oxford Handbook of Innovation, Oxford University Press, 240-265.

Park, R. E. (1966). Estimation with Heteroscedastic Error Terms. Econometrica, 34, 888. https://doi.org/10.2307/1910108

Park, N. K., Park, U. D., \& Lee, J. (2012). Do the Performances of Innovative Firms Differ Depending on Market-oriented or Technology-oriented Strategies? Industry and Innovation, 19(5), 391-414. https://doi.org/10.1080/13662716.2012.711024

Parry, M. E., \& Song, X. M. (1993). Determinants of R\&D-marketing integration in high-tech Japanese firms. $\begin{array}{lllll}\text { The Journal of Product Innovation Management, } & \text { 10(1), 4-22. }\end{array}$ https://doi.org/10.1016/0737-6782(93)90050-Z

Patel, P., \& Pavitt, K. (1995). Patterns of Technological Activity: Their Measurement and Interpretation. In Stoneman, P. (Ed.). Handbook of the Economics of Innovation and Technological Change. Oxford, Blackwell, 14-51.

Pavitt, K. (1984). Sectoral patterns of technical change: Towards a taxonomy and a theory. Research Policy, 13(6), 343-373. https://doi.org/10.1016/0048-7333(84)90018-0

Pavitt, K., Robson, M., \& Townsend, J. (1989). Technological accumulation, diversification and organisation in UK companies. Management Science, 35(1), 81-99. https://doi.org/10.1287/mnsc.35.1.81

Peters, M., Schneider, M., Griesshaber, T., \& Hoffmann, V. H. (2012). The impact of technology-push and demand-pull policies on technical change-Does the locus of policies matter? Research Policy, 41(8), 1296-1308. https://doi.org/10.1016/j.respol.2012.02.004

Petersen, M. A., \& Rajan, R. G. (1995). The effect of credit market competition on lending relationships. Quarterly Journal of Economics, 110(2), 407-443. https://doi.org/10.2307/2118445

Piva, M., \& Vivarelli, M. (2007). Is demand-pulled innovation equally important in different groups of firms? Cambridge Journal of Economics, 35(1), 691-710. https://doi.org/10.1093/cje/bem010

Pla-Barber, J., \& Alegre, J. (2007). Analysing the link between export intensity, innovation and firm size in a science-based industry. International Business Review, 16(3), 275-293. https://doi.org/10.1016/j.ibusrev.2007.02.005

Rennings, K., \& Rammer, C. (2011). The impact of regulation-driven environmental innovation on innovation success and firm performance. Industry and Innovation, 18(3), 255-283. https://doi.org/10.1080/13662716.2011.561027

Rosenberg, N. (1969). The Direction of Technological Change: Inducement Mechanisms and Focusing Devices. 
Economic Development and Cultural Change, 18(1), 1-24. https://doi.org/10.1086/450399

Rosenberg, N. (1974). Science, invention and economic growth. The Economic Journal, 84(333), 90-108. https://doi.org/10.2307/2230485

Rosenberg, N. (1990). Why do firms do basic research (with their own money)? Research Policy, 19(2), 165-174. https://doi.org/10.1016/0048-7333(90)90046-9

Rosenberg, N. (1994). Exploring the Black Box: Technology, Economics, and History. Cambridge University Press: Cambridge. https://doi.org/10.1017/CBO9780511582554

Schafer, D., Werwatz, A., \& Zimmermann, V. (2004). The determinants of debt and (private) equity financing: The case of young, innovative SMEs from Germany. Industry and Innovation, 11(3), 248-255. https://doi.org/10.1080/1366271042000265393

Schmookler, J. (1962). Economic Sources of Inventive Activity. The Journal of Economic History, 22(1), 1-20. https://doi.org/10.1017/S0022050700102311

Schmookler, J. (1966). Invention and Economic Growth. Harvard University Press. https://doi.org/10.4159/harvard.9780674432833

Singla, A., Ahuja, I. S., \& Sethi, A. P. S. (2018). Technology push and s practices for achieving sustainable development in manufacturing industries. Journal of Manufacturing Technology Management, 29(2), 240-272. https://doi.org/10.1108/JMTM-07-2017-0138

Sorensen, J. B., \& Stuart, T. E. (2000). Aging Obsolescence, and Organizational Innovation. Administrative Science Quarterly, 45(1), 81-112. https://doi.org/10.2307/2666980

Souitaris, V. (2002). Technological trajectories as moderators of firm-level determinants of innovation. Research Policy, 31(6), 877-898. https://doi.org/10.1016/S0048-7333(01)00154-8

Sparks, R. S., Zucchini, W., \& Coutsourides, D. (1985). On Variable Selection in Multivariate Regression. Communications. Statistics Theory and Methods, 1569-1587. https://doi.org/10.1080/03610928508828996

Stiglitz, J. (1985). Credit Markets and Capital Control. Journal of Money, Credit and Banking, 17(2), 133-152. https://doi.org/10.2307/1992329

Stiglitz, J. E., \& Weiss, A. (1981). Credit Rationing in Markets with Imperfect Information. American Economic Review, 71(3), 393-410.

Ughetto, E. (2008). Does finance matters for R\&D investment? New evidence from a panel of Italian firms. Cambridge Journal of Economics, 32(6), 907-925. https://doi.org/10.1093/cje/ben015

Von Hippel, E. (1976). The dominant role of users in the scientific instrument innovation process. Research Policy, 5(3), 212-239. https://doi.org/10.1016/0048-7333(76)90028-7

Von Hippel, E. (1994). "Sticky information" and the locus of problem solving: implications for innovation. Management Science, 40(4), 429-439. https://doi.org/10.1287/mnsc.40.4.429

Von Hippel, E. (2001). Perspective: User toolkits for innovation. Journal of Product Innovation Management, 18(4), 247-257. https://doi.org/10.1016/S0737-6782(01)00090-X

Wesley, M., Cohen, D. L., Cohen, W. M., \& Levinthal, D. (1989). Innovation and Learning: The two faces of R\&D. The Economic Journal, 99(397), 569-596. https://doi.org/10.2307/2233763

White, H. (1980). A Heteroscedasticity Consistent Covariance Matrix Estimator and a Direct Test of Heteroscedasticity. Econometrica, 48, 817-818. https://doi.org/10.2307/1912934

Wu, W. Y., Chang, M. L., \& Chen, C. W. (2008). Promoting innovation through the accumulation of intellectual capital, social capital, and entrepreneurial orientation. $R \& d$ Management, 38(3), 265-277.

Zahra, S. A., \& George, G. (2002). Absorptive capacity: A review, reconceptualization, and extension. Academy of Management Review, 27(2), 185-203. https://doi.org/10.5465/amr.2002.6587995 
Appendix 1. Variables description

\begin{tabular}{|c|c|c|c|c|}
\hline Variable & Label & Type & EFIGE-dataset: code and item & Values \\
\hline \multicolumn{5}{|l|}{ Dependent variable } \\
\hline $\begin{array}{l}\text { "Innovation investment } \\
\text { propensity of the firm" }\end{array}$ & INN_PRO & categorical & $\begin{array}{l}\text { C29-Q: During } 2009 \text {, has your firm decided } \\
\text { to postpone investments in product or } \\
\text { process innovation? }\end{array}$ & $\begin{array}{l}0 \text { "Yes" } \\
1 \text { "No" } \\
\text { (recoded) }\end{array}$ \\
\hline \multicolumn{5}{|l|}{ Independent variables } \\
\hline $\begin{array}{l}\text { Technology-push determinant } \\
\text { "The percentage of university } \\
\text { graduates in the workforce " }\end{array}$ & GRAD & scale & $\begin{array}{l}\text { B6_1-Q: What is the percentage/number of } \\
\text { university graduate in your workforce in } \\
\text { your home country? (Percentage in 2008) }\end{array}$ & 0 to 100 \\
\hline $\begin{array}{l}\text { Demand-pull determinant } \\
\text { "the percentage of firms' } \\
\text { turnover made up by sales of } \\
\text { produced-to-order goods" }\end{array}$ & $\mathrm{PO}$ & scale & $\begin{array}{l}\text { E1-Q: Can you please indicate which } \\
\text { percentage (on average) of your firm's } \\
\text { turnover was made up by sales of } \\
\text { produced-to-order goods (in 2008) }\end{array}$ & 0 to 100 \\
\hline \multicolumn{5}{|l|}{ Control variables } \\
\hline $\begin{array}{l}\text { "Financial incentives provided } \\
\text { by the public sector" }\end{array}$ & BEN_PUB & categorical & $\begin{array}{l}\text { F23-Q: During the last year did the firm } \\
\text { benefit from financial incentives provided by } \\
\text { the public sector? }\end{array}$ & $\begin{array}{l}1 \text { "Yes" } \\
0 \text { "No" } \\
\text { (recoded) }\end{array}$ \\
\hline $\begin{array}{l}\text { "Benefits from special tax } \\
\text { allowances and/or financial } \\
\text { incentives" }\end{array}$ & BEN_INV & categorical & $\begin{array}{l}\text { C13a-Q: During the } 2009 \text { has the firm } \\
\text { benefitted from special tax allowances } \\
\text { and/or financial incentives? }\end{array}$ & $\begin{array}{l}1 \text { "Yes" } \\
0 \text { "No" }\end{array}$ \\
\hline "Intra-group financing" & GROUP & categorical & A8-Q: Does your firm belong to a group? & $\begin{array}{l}1 \text { "Yes" } \\
0 \text { "No" }\end{array}$ \\
\hline \multicolumn{5}{|l|}{ "Firm's size" } \\
\hline Number of employee & EMPL & scale & $\begin{array}{l}\text { B3-Q: Please indicate the total number of } \\
\text { employees of your firm in your home } \\
\text { country in } 2008\end{array}$ & 10 to 500 \\
\hline Turnover & TUROV & & $\begin{array}{l}\text { A3-Q: In which of the following ranges falls } \\
\text { the annual turnover in } 2008 \text { of your firm? }\end{array}$ & $\begin{array}{l}\text { less than } 1 \text { million } \\
\text { euro to more than } \\
250 \text { million euro }\end{array}$ \\
\hline
\end{tabular}

\section{Copyrights}

Copyright for this article is retained by the author(s), with first publication rights granted to the journal.

This is an open-access article distributed under the terms and conditions of the Creative Commons Attribution license (http://creativecommons.org/licenses/by/4.0/). 